石油技術協会誌 第 66 巻 第 6 号 (平成13年11月)

JOURNAL OF THE JAPANESE ASSOCIATION FOR PETROLEUM TECHNOLOGY

VOL. 66, NO. 6 (Nov., 2001)

資料

開発・生産部門シンポジゥム

「油・ガス田開発のリスク評価」

SYMPOSIUM

\title{
Risk evaluation in development of oil and gas fields
}

\author{
開 会 の 挨 拶* \\ 世話人**代表 佐野 正治***
}

Opening address by Masaharu Sano

皆様, おはようございます。私は石油技術協会の生産 技術委員長を務めております佐野でございます。今年度 春季講演会の開発・生産部門シンポジゥムを開催するに 当たり，一言ご挨拶申し上げます。

本日は雨の中を多数ご参加いただき, ありがとうござ います。今日は十分皆様にリスク評価をしていただき， 俗に言うリスクに見合うリターンをここで得て帚ってい ただければと思っております。今回, 開発生産部門のシ ンポジゥムに「油・ガス田開発のリスク評価」という テーマを選んだわけですが, 会の始めに当たりましてこ の背景をご説明させていただきます。

これまで石油技術協会は，技術という名がついている とおり, 開発生産部門ですと, 地下の油層のことや坑井 の掘削・仕上げ, あるいは生産設備といった技術的な論 議や事例の紹介, 共有というようなテーマで代々シンポ ジゥムが行われてきました。そういう分野での技術革

* 平成 13 年 5 月 31 日, 平成 13 年度石油技術協会春季講演会開 発・生産部門シンポジゥム「油・ガス田開発のリスク 評価」での挨拶 Opening address at the 2001 JAPT Development and Production Technology Symposium entitled "Risk evaluation in development of oil and gas fields" held in Makuhari, Chiba, Japan, May 31, 2001.

** 世話人 : 矢澤仁徳 (公団技術センター), 吉良仁秀 (日石 開発), 難波隆夫 (公団本部), 鈴木孝一 (ジャパン石開), 影山隆 (石資本社), 藤原勝憲 (ジャパンエナジー石開), 加賀野井彰一（帝石技研）

****生産技術委員会委員長, 帝国石油(侏)

Copyright (C) 2001, JAPT
新, 例えば油層シミュレーション, 水平坑井あるいは坑 井刺激など，いろいろな要素について深く論議するとい うような傾向でありましたが, 一方では最近各分野の細 分化あるいは専門化が進んでおり，それらを横断的につ ないでいろいろな分野の方の括をうかがう，マルチ・ ディシィプリナリというあのをやってみようではないか という声屯強く出てきています。生産技術委員会の中だ けを取りますと，そういう意図を受けっつ今年の春から 埋蔵量・資源量に関する分科会, また, ガスの取り扱い というようなことでのガス攻法分科会, の 2 つを立ち上 げてきております。さらに各委員会で共同して提案され たワークショップあ明日開かれることになっておりま す。

そこで, 今回のここでのシンポジウムのテーマあその 一環として, 少し大上段というところはありますが, 横 断的なこのテーマを選んだ次第です。リスクというと 「リスクを取る」とか「リスクの回避」,「リスクの分散」 などと一般的な名詞として言葉自体はよく聞かれます。 では, リスクとは本当は何を意味するのかということで 辞書を引いてみますと, 例えば広辞苑などでは、「危険」, 「非保険物」としか書いてありません。このような非常 にリスクを取らない表現しか出ていないのですが，われ われが主にやっております石油の上流部門というのは, まさにリスクそのあのだというように思います。そこ で，今回こういう場で，取るべきリスクとはどんなすの なのか，あるいは技術の進歩でどのようなリスクの最小 化ができているのか，といったことについて，技術的な 
面のみならず経済的な面での論議もできればと思ってお ります。

石油・ガスのビジネスというと，これは地球46億年の 歴史の賜物であり，それから貴重なる資源を地上に出す というまさに理系, 文系というか, 理学, 工学, あるい は経済学，心理学というようなあのまでを網羅するよう な世界だと思います。そのあたりが冒頭申しました若干 大上段のテーマというところなのですが，このテーマを 一日で語りきるというようなことはなかなか難しいで しょう。とはいえ，本日ご講演いただく㫮様のお話，そ れからこの会の最後にあるパネルディスカッションを通
じて，ご参集いただいた皆様が何らかのテーマに関して 刺激あるいは知識を得てお帰りいただければと思いま す。ぜひ，活発な論議をお願い致します。

最後になりますが，今回，このシンポジゥムは作井技 術委員会との協調として, 横断的な試みの第一歩として 作井技術委員会から講演及びパネルに参加いただいてお ります。また，資源経済委員会からあ参加をお願いして りおります。この場を借りて感謝申し上げたいと思いま す。それでは今日一日, 皆様, よろしくお願い致しま す。 